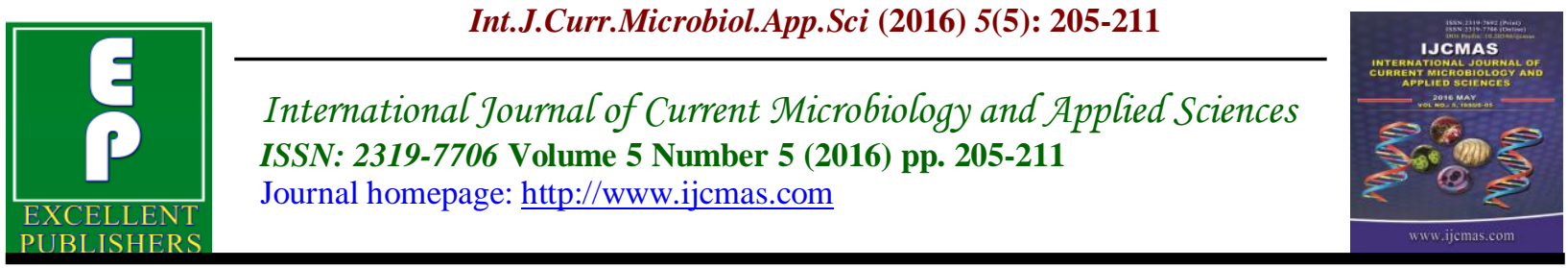

Original Research Article

http://dx.doi.org/10.20546/ijcmas.2016.505.022

\title{
New Record of Liriomyza trifolii (Burgess, 1880) (Diptera; Agromyzidae) in Baghdad, Iraq
}

\section{Redha S. AL-Jorany*, Sawsan Kareem Flaih, Shaymaa Abdulkhaliq Alhamawandy and Hanaa Hani Al-saffar}

\author{
Department of Plant Protection, College of Agriculture, University of Baghdad, Iraq \\ *Corresponding author
}

\begin{tabular}{|c|c|}
\hline & A B S T R A C T \\
\hline Keywords & \multirow{4}{*}{$\begin{array}{l}\text { This study was conducted to evaluate the leaf miner Liriomyza spp. in fields } \\
\text { of Agriculture Collage, University of Baghdad. Infested leaves were } \\
\text { collected weekly during } 2015-2016 \text {, then brought to laboratory and kept } \\
\text { under lab temperature until the leaf miner adults were emerging. Liriomyza } \\
\text { trifolii (Burgess, 1880) was recorded as a new record for Iraqi fauna. The } \\
\text { pest were found infected Abelmoschuses culentus, Vigna spp and Ricinus } \\
\text { communis. }\end{array}$} \\
\hline $\begin{array}{l}\text { Agromyzidae, } \\
\text { Baghdad, } \\
\text { leafminer, } \\
\text { liriomyza, pests. }\end{array}$ & \\
\hline Article Info & \\
\hline $\begin{array}{l}\text { Accepted: } \\
12 \text { April } 2016 \\
\text { Available Online: } \\
10 \text { May } 2016\end{array}$ & \\
\hline
\end{tabular}

\section{Introduction}

The Agromyzidae family is a large and diverse family of flies composed exclusively of phytophagous species. Their host-plants range from wild to cultivated species, thus consist of important pests group in agriculture. Family is widely distributed through the world in southern hemisphere than in temperate areas of Palaearctic and Nearctic regions (Spencer, 1972) it studies in different region of the world (Spencer, 1961, 1963).

A worldwide family has about 2,500 species, small insects, some with wing length of $1 \mathrm{~mm}$. The maximum size is $6.5 \mathrm{~mm}$. Most species are in the range of 2 to $3 \mathrm{~mm}$.
Agromyzid adults can be diagnosed by the distinctive sclerotization of head. Top upper section of frons, above ptilinal suture (known as frontal vitta) is lightly sclerotized and lacks setae, while lower section of the frons and the dorsal region of the head tends to be much more heavily sclerotized and setaceous. Thus, the frontal vitta often forms a distinctive patch on the head, different in colour and texture from the rest of the head. The compound eyes are usually oval and fairly small, although in some species, they are larger and more circular.

The wings are usually diaphanous. More over, there are some tropical species have 
darker markings. A some species, including most species Agromyza spp., are capable of stridulation, owning a "file" on the first part of the abdomen segment and a "scraper" on the hind femur (Wikipedia, 2015).

The family of Agromyzidae is subdivided in two sub families (Agromyzinae and Phytomyzinae). In the sub family Agromyzinae the subcostal is fully developed and joins vein R1before this reaches the costa most species are large and stout, with Estimated length of the wing almost $3 \mathrm{~mm}$, and the costa generally extends strongly to vein $M 1+2$. In the larvae phase exist is a third, upper arm of the cephalo-pharyngeal skeleton.

Phytomyzinae diagnosed by subcostal vein is greatly reduced, frequently being little more than a fold running parallel to first radial vein (R1) and joining costa independently; in several genera costa is reduced and terminates at the apex of vein $\mathrm{R} 4+5$. The largest species in family occur in primitive genus, Phytobia Lioy, 1864, but many species are smaller, more slender and even minute, with wing length of less than 2 $\mathrm{mm}$. The cephalopharyngeal skeleton of larva has only two arms (Spencer, 1977; 1989 and 1990).

Liriomyza, consist of about 376 species (Spencer, 1987; EPPO, 2005), but in Iraq showed such as: (Al Ali, 1977; Al-Azzawi, 1980; Abdul-Rassoul and Al- Saffar, 2013).

The punctures that it causes by females through the feeding and oviposition processes can led to a stippled appearance on foliage, mostly at the leaf tip and along the leaf margins (Parrella, et al., 1981). In addition to, the major form of damage is the mining of leaves by larvae, which results in destruction of leaf mesophyll. The mine becomes noticeable after three to four days fromovi position and appear larger in size as the larva matures. Often, The pattern of mining is irregular. Both leaf mining and stippling can greatly lower the level of photosynthesis in the infected plant. Extensive mining also causes premature leaf drop, which can lead to lack of shading and sun light that scald of fruit. Wounding of the foliage also allows entry of bacterial and fungal diseases in to plant.

The host plants of Liriomyza trifolii is highly polyphagous and has been recorded from 25 families (Spencer, 1990). The More crops that are attack by this insect are celery, beans, chrysanthemum, gerbera, cucumber, gypsophila, lettuce, onion, tomato and potato (Spencer, 1989).

The biology of $L$. trifolii eggs are inserted just below the leaf surface. The number of eggs laid differs according to host plant and temperature. L. trifolii mature females each laid 25 eggs in celery plant at $15^{\circ} \mathrm{C}$ and 400 eggs at temperatures around $30^{\circ} \mathrm{C}$. One female of L. trifolii laid 493 eggs in peas crop (Poe, 1981).

Eggs hatch in 2-5 days according to temperature. The duration of larval development as well differs with temperature and host plant but is generally 4-7 days at mean temperatures above $24^{\circ} \mathrm{C}$ (Harris and Tate, 1933). In Phaseolus, at a constant $30^{\circ} \mathrm{C} \mathrm{L}$. trifolii larvae complete development in 4 days and at $20^{\circ} \mathrm{C}$ within 7 days (Poe, 1981).

The insect L. trifolii pupariates externally, either on the foliage or in the soil just beneath the surface. It has also been Notes to pupariate in the leaf of, for example, onion and lucerne (Harris and Tate, 1933; Webster and Parks, 1913). Pupariation is adversely Influenced by increase humidity and drought. 
Adult emergence of Liriomyza species occurs 7-14 days after pupariation, (Leibee, 1982). Mating Occur immediately after $24 \mathrm{~h}$ than the emergence and a single mating (Parrella et al., 1981).

\section{American Serpentine Leaf miner}

The economic importance of pests, and its presence newly in the study are in Baghdad, this study was conducted which include the description and diagnosis.

\section{Materials and Methods}

Many infested of leaf were collected from oil castor plant Ricinus communis, Abelmoschuses culntus and Vigna spp from AL-Jadyria / University of Baghdad, Which attacked by pest Liriomyza trifolii, during $1 / 10 / 2015$ to $30 / 1 / 2016$, brought to the laboratory and kept in petri dishes at room temperature, the microscopic examination carry out a daily to monitor the emergence of adult. After 10-20 days, the flies were left the leaf as adult and which keptin gelatinized capsules in order to the Iraq Natural History Research Center and
Museum for diagnosis them(Spencer,1961, Spencer,1963 and Spencer,1972,Shiao, et al., 1991; Shiao, 2004 and Anderson et al., 2008).

\section{Results and Discussion}

The study explained that the eggs of $L$. trifolii off white and half diaphanous, eggs are Length 0.2-0.3 mm x Width 0.1-0.15 $\mathrm{mm}$ (Figure1). Describes distinguishing features of the larvae (Figure2).

L. trifolii larva is up to $3 \mathrm{~mm}$ long, Larva is a legless larva with no discrete head capsule, transparent when newly hatched but colouring up to a yellow-orange in later phases and puparia have a pair of rearward spiracles ending in three cone-like appendages Pupaisa changeable colour pale yellow-orange, blackout to golden-brown, with oval shape and somewhat flattened ventral side, Length 1.3-2.3 xWidth 0.5-0.75 $\mathrm{mm}$, The puparium has rearward spiracles on a marked pronounced conical projection, each with three featured bulbs, two of which are elongate. Pupariation occurs outside the leaf, in the soil under the plant (Figure3).

Fig.1 Eggs of L. trifolii

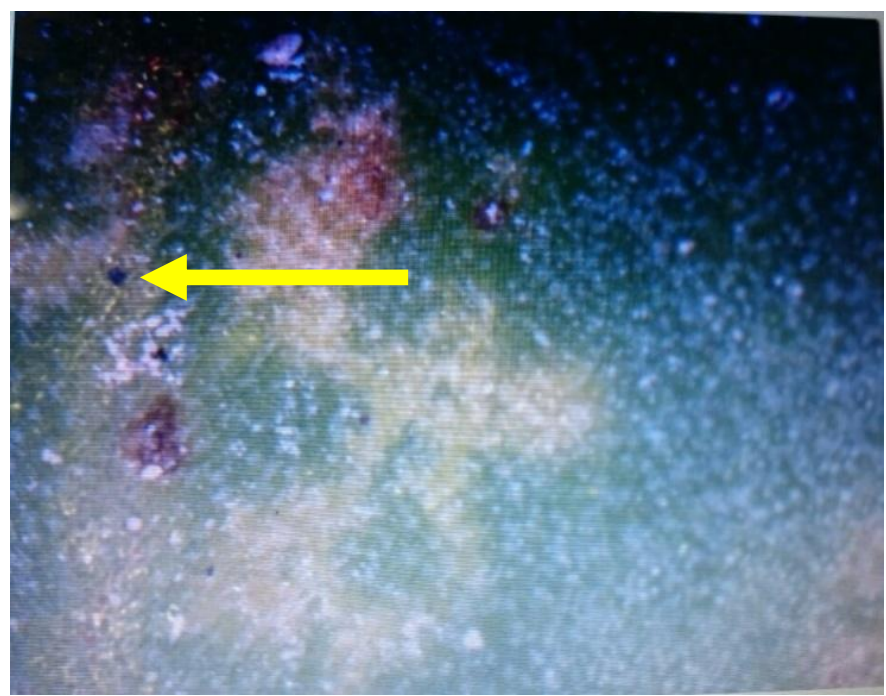

Fig.2 Larvae of L. trifolii 


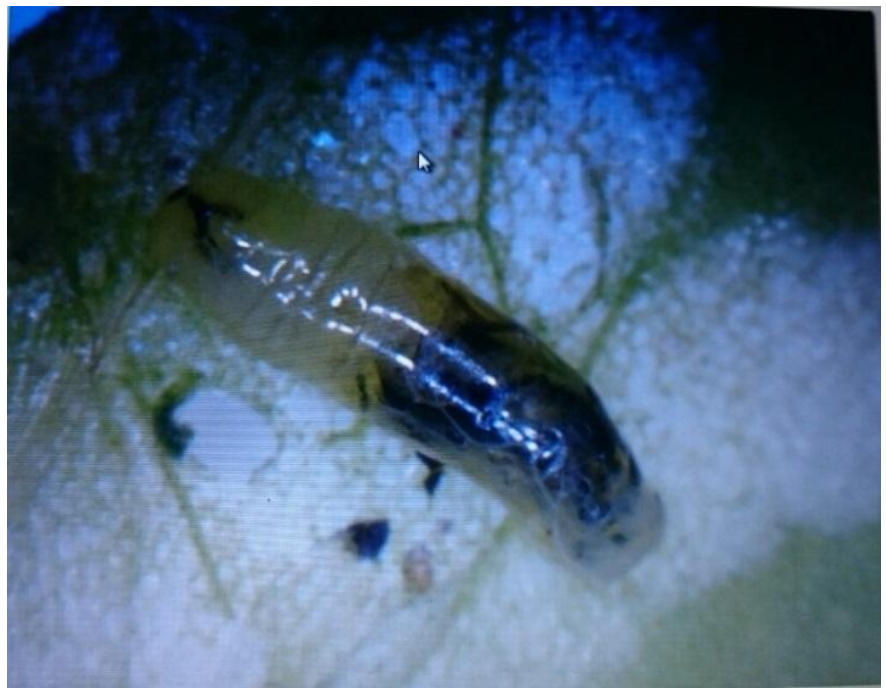

Fig.3 Pupa of L. trifolii

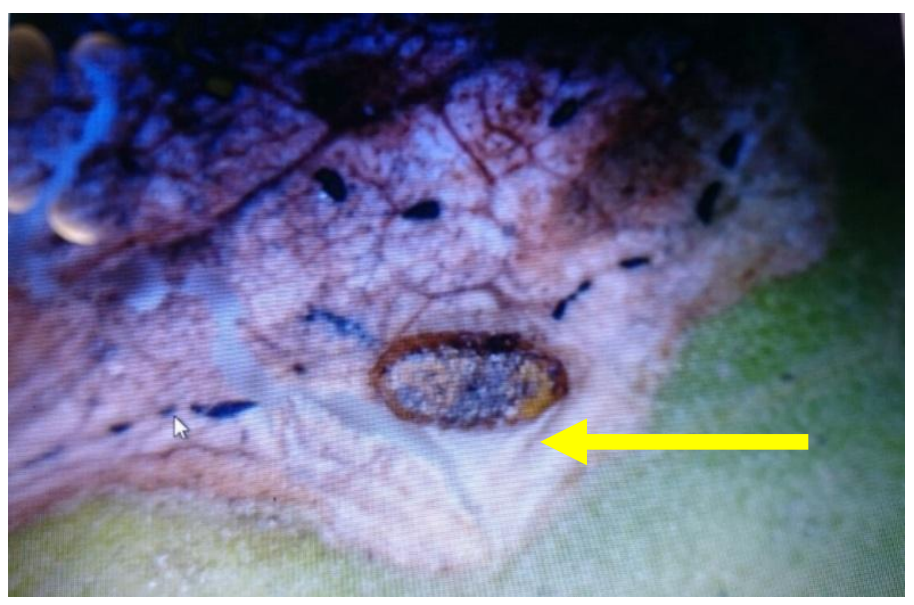

Fig.4 Head of L. trifolii
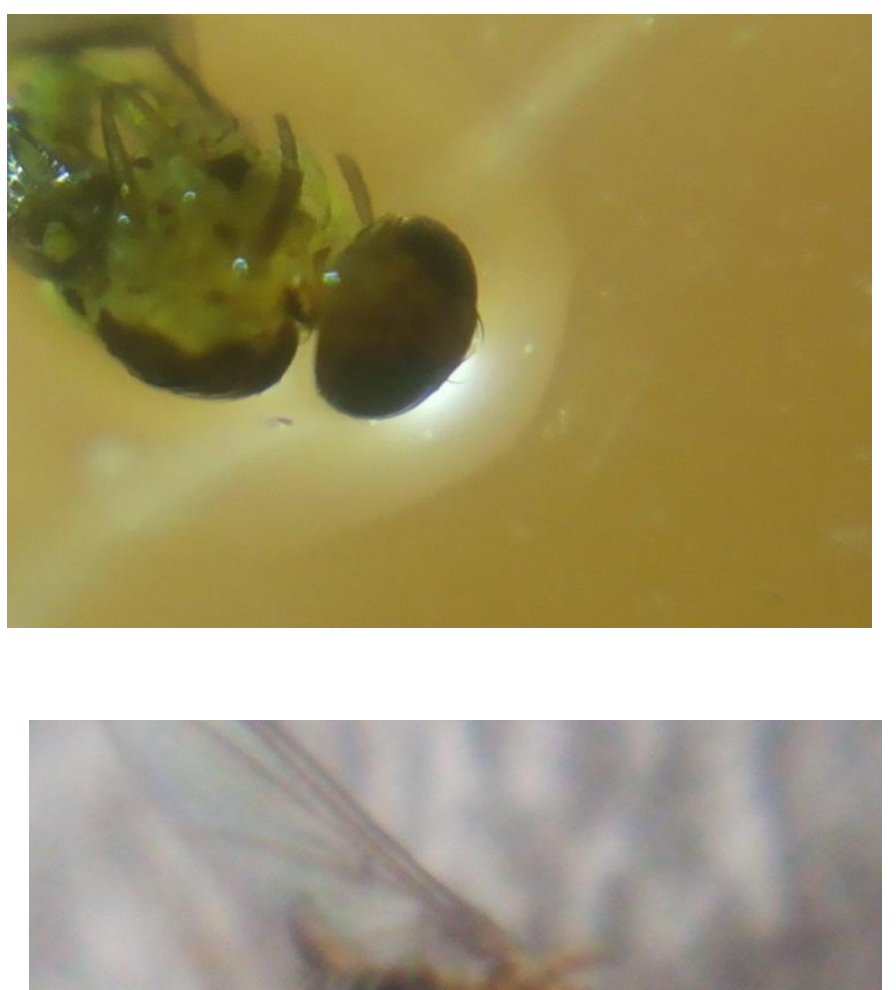
Fig.6 Adult of L. trifolii

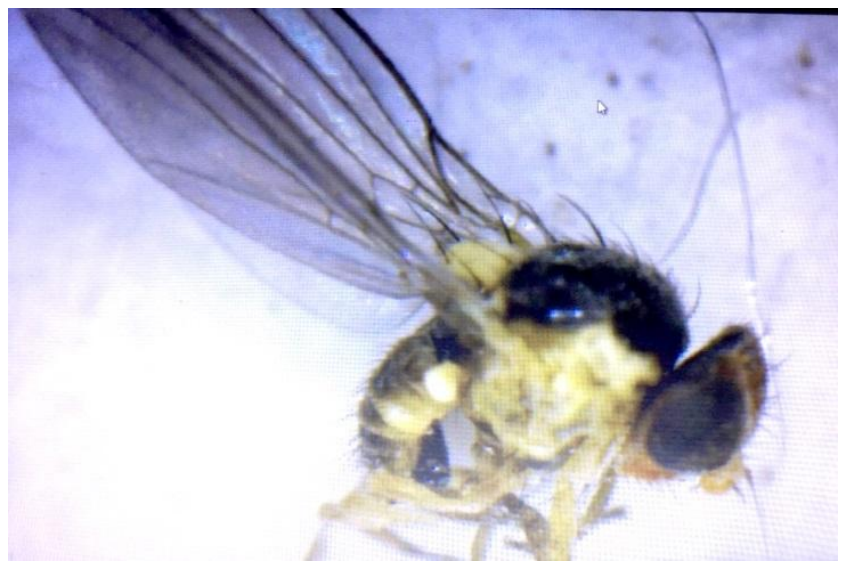

Fig.7 Wing of L. trifolii

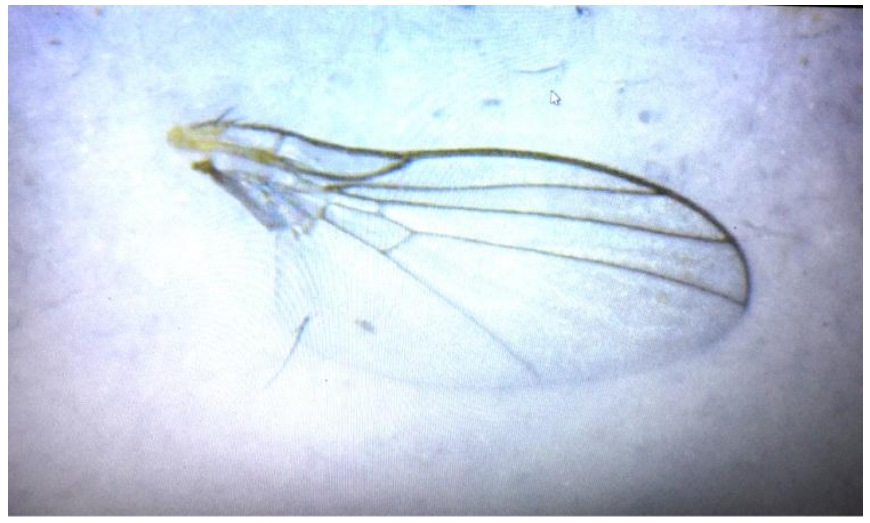

Head contains, the frons which projects very slightly above the eye, is just less than 1.5 times from the width of the eye (viewed from above (visible from the top). There are two equal superior orbital setae and two internal orbital setae (the lower one weaker). The orbital setulae are sparse and reclinate. The jowls are deep (almost 0.33 times the 
height of the eye at the rear); the cheeks form a clear ring under the eye. The third antennal segment is small, round and marked pubescent, but not excessively so (external vertical rough and inner vertical coarseare both on a yellow ground) (Figure 4).

Mesonotum, acrostical bristles happen irregularly in 3-4 rows on the front, decline to two rows behind. There is a conspicuous yellow patch at each hind-corner. The pleura are yellow color; the meso- and sternopleura have variable Black marking (Figure $5)$.

Adult of $L$. trifoliiis very small in volume: (1-1.3 mm)from body length, up to $(1.7 \mathrm{~mm})$ in female with wingsA length (1.3-1.7 mm). The mesonotum is grey-black color with a yellow blotch at the hind-corners. The scutellum is bright yellow color; the face, frons and third antennal segment are bright yellow. Male and female L. trifolii are generally identical in morphological (Figure 6). Wing, length $1.3-1.7 \mathrm{~mm}$, discal cell small. The last section is $\mathrm{M}<(\mathrm{sub}) 3+4>$ from 3-4 times the length of the penultimate one (Figure 7).

\section{Host Plants}

L. trifolii were found infested the leaves of Ricinus communis, Abelmoschuses culntus and Vigna spp.

\section{References}

Al-Azzawi, A.H. 1967. Agromyzid leafminers and their parasite in Iraq. Bull. Entomol. Res., 57(2): 285-287.

Al-Ali, A.S. 1977. Phytophagous and entomophagous insect and mites of Iraq. Nat. Hist. Res., Cent, Publ. No. 33: 142pp.
Abd AL-Rassoul, M.S., Hanaa, H.S. 2013. Survey of the genus Liriomyza Mik. (Diptera: Agromyzidae) of Iraq. $A d v$. Biores., Vol 4(3): 92-94.

Anderson, A., Tan, T.T.A., Nordhus, E. 2008. Diatripution and importance of polyphagous Liriomyza species (Diptera: Agromyzidae) in vegetables in Vietnam.

Elliott, M.G. 2006. Diptera: Cyclorrhapha: (Acalyptrata: Part): Agromyzidae. Australian Faunal Directory. Australian Biological Resources Study, Canberra. Viewed $22 \quad$ January 2008. http://www.environment.gov.au/biodiv ersity/abrs/online resources/fauna/afd/index.html direct link to Agromyzidae checklist

EPPO. 2005. Liriomyza spp. EPPO Bull., 35: 335-344.

Harris, H.M., Tate, H.D. 1933. A leafminer attacking the cultivated onion. $J$. Economic Entomol., 26: 515-516.

Leibee, G.L. 1982. Development of Liriomyza trifolii on celery. In: Proceedings of IFAS (Institute of Food $\&$ Agricultural Sciences, University of Florida) Industry Conference on Biology and Control of Liriomyza leaf miners, Lake Buna Vista, Florida, USA, 35-41.

Oldroyd, H. 1970. Diptera 1. Introduction and key to families. Handbook for the Identification of British Insects. 3rd Edition. Royal Entomological Society of London, London.

Parrella, M.P., Allen, W.W., Morishita, P. 1981. Leaf-miner species causes California mum growers new problems. California Agri., 35(9/10): 28-30.

Parrella, Michael, P., Clifford, B., Keil. 1985. Toxicity of methalvlidophos to four species of agromyzidae. J. Agric. Entomol., 2(3): 234-237. 
Petitt, F.L. 1990. Distinguishing larval instars of the vegetable leafminer Liriomyza sativae (Diptera: Agromyzidae). Florida Entomol., 73(2): 280-286.

Poe, S.L 1981. Miner notes. Society of American Florists, 2: 1-10.

Ricardo Gilortiz. 2009. Biosystamatic contribution to Agromyzidae. Thesis Doctoral University Politecinica DE Valencia. pp. 422.

Shaio, Sh.F., Lin, F.J., Wu, W.J. 1991. Redescription of four Liriomyza species (Diptera: Agromyzidae) from Taiwan. Chinese J. Entomol., 11(1): 65-74.

Shaio, Sh.F. 2004. Morpholgical diagnosis of six Liriomyza species (Diptera: Agromyzidae) of quarantine importance in Taiwan. Appl. Entomol. Zool., 39(1): 27-39.

Spencer, K.A. 1961. A synopsis of the Oriental Agromyzidae (Diptera). Trans. R. Entomol. Soc. Lond., 113Pt.4: 55-1003.

Spencer, K.A. 1963. A synopsis of the Neotrophora Agromyzidae(Diptera). Trans. R. Entomol. Soc. Lond., 115Pt.12 : 291-389.

Spencer, K.A. 1972. Diptera Agromyzidae. In: Handbook for the identification of British insects, 10(5g): 1-136.
Spencer, K.A. 1972. Diptera, Agromyzidae. Royal Entomological Society of London Handbooks for the Identification of British Insects 10, Part 5(g): 1-136.

Spencer, K.A. 1977. A revision of the Australian Agromyzidae (Diptera). Special Publication. Western Australian Museum, 8: 1-255.

Spencer, K.A. 1987. Agromyzidae. In Manual of Nearctic Diptera, 2. Monograph no. 28. (edsMcAlpine JF, Peterson BV, Shewell GE, Teskey HJ, Vockeroth JR \& Wood DM), pp. 869879. Research Branch Agriculture Canada, Ottawa, Canada.

Spencer, K.A. 1989. Leaf miners. In Plant Protection and Quarantine, Vol. 2, Selected Pests and Pathogens of Quarantine Significance (ed Kahn RP). CRC Press, Boca Raton, pp. 77-9.

Spencer, K.A. 1990. Host specialization in the world Agromyzidae (Diptera). Dordrecht, Netherlands: Kluwer Academic Publishers, pp. 444.

Webster, F.M., Parks, T.H. 1913. The serpentine leafminer. J. Agri. Res., Washington D.C. 1: 59-87.

Wikipedia, the free encyclopedia. 2015.

\section{How to cite this article:}

Redha S. AL-Jorany, Sawsan Kareem Flaih, Shaymaa Abdulkhaliq Alhamawandy and Hanaa Hani Al-saffar. 2016. New Record of Liriomyza trifolii (Burgess, 1880) (Diptera; Agromyzidae) in Baghdad, Iraq. Int.J.Curr.Microbiol.App.Sci. 5(5): 205-211. doi: http://dx.doi.org/10.20546/ijcmas.2016.505.022 